\title{
Male breast tumors and oxidative DNA damage
}

Estabraq AR. Al-Wasiti ${ }^{1 *}$

\begin{abstract}
Male breast cancer is a rare compared to its female counterpart and makes less than $1 \%$ of all breast cancer. Risk factors for breast cancer in men, including genetic, hormonal and environmental factors, provide parallels to the etiology of breast cancer in women. To evaluate whether deficient DNA repair contributes to elevated DNA damage and breast carcinogenesis, this study used comet assay (single-cell alkaline gel electrophoresis) to measure the levels of DNA damage in peripheral leukocytes and tissue from 20 breast tumor cases and 20 controls (only peripheral leukocytes). The results showed that cancer cases had significant higher DNA damage compared with controls and benign cases, the comet tail moments (mean \pm SD) for cases (benign and cancer) and controls were: $5.64 \pm 0.88,7.93 \pm 0.82$ and $3.18 \pm 0.74$ respectively. For tissue the cancer cases showed higher DNA damage compared with begin breast tumors $(15.33 \pm 0.92$ and $11.24 \pm 1.57)$. Smoking status was causes to increase DNA damage in the Leukocyte of the patients with benign breast tumors and breast cancer when compared to nonsmoking cases the (mean $\pm \mathrm{SD}$ ) for benign $(5.17 \pm 0.71$ versus $6.47 \pm 0.41$ ) while for malignant tumors were (7.25 \pm 0.62 versus $8.0 \pm 0.39)$. As body mass index (BMI) increase will causes increases in DNA damage for benign and malignant breast tumor. In conclusion our results support the hypothesis that increased breast cancer risk is associated with higher DNA damage and evaluation of DNA damage response may contribute to early detection and prevention of breast cancer.
\end{abstract}

Keywords: Comet assay; Oxidative DNA damage; Male breast cancer

"Corresponding Author E-mail: estabraqalwasiti@yahoo.com

1Department of chemistry and biochemistry in Al-Nahrain University/ College of Medicine

Received December 23, 2015; accepted May 12, 2016; published June 11, 2016

Copyright $\odot 2016$ EA. This is article distributed under the terms of the Creative Commons Attribution

License (http://creativecommons.org/licenses), which permits unrestricted use, distribution, and

reproduction in any medium, provided the original work is properly cited.

\section{Introduction}

Male breast cancer is rare compared to its female counterpart and makes less than $1 \%$ of all breast cancer. Its etiology is less known than that of female breast cancer. Numerous experimental and clinical studies indicate the possibility of an increased risk of male breast cancer in workers occupationally exposed to electromagnetic field, light at night, and high temperature. There are also studies, which reveal the increased risk of this disease induced by occupational exposure to pesticides, aromatic hydrocarbons and ionizing radiation [1]. In addition, bilateral breast cancer accounts for only $1.5-2 \%$ of MBC, and a simultaneous cancer is extremely rare [2-5]. The consensus is that MBC is caused 
by an imbalance between estrogen and testosterone $[6,7]$.

Cancer as a disease is intimately associated with DNA damage at multiple levels $[4,5]$. Elevated DNA damage levels or unrepaired DNA damage and suboptimal DNA repair may cause mutations or chromosomal aberrations that contribute to malignant transformation and cancer risk. At the cellular and molecular levels, genes whose products participate in complex responses to DNA damage are commonly deregulated or inactivated in tumors $[4,5]$. Such defects in DNA damage recognition, signaling and/or downstream responses, including cell-cycle checkpoints, DNA repair or cell death, allow the genetically unstable cancer cells to survive, proliferate and acquire even more genetic instability-4) [8-9].

Various biomarkers have been used to determine cellular DNA damage. The single-cell gel electrophoresis, or the Comet assay, is a valuable Method for the assessment of DNA strands breakage in a single cell. It is based on the alkaline lysis of labile DNA at sites of damage. The assay is relatively easy to perform and well-suited for population-based studies [10-14].

While much is known in female breast cancer very little has been written about male breast cancer. For this reason; the aim of this study was to investigate the DNA damage in peripheral blood leukocyte and tissue from patients with benign and malignant breast tumors in comparison to healthy controls by using the comet assay.

\section{Materials and Methods}

\section{Study population}

The study included 40 males; of these, 20 were newly diagnosed untreated breast tumors with an age range of 24-65year.
They were admitted to the Department of surgery Al-Khadymia Teaching Hospital during the period of December, 2004 to December, 2006. Moreover, 20 healthy controls (age range 24-65 year) with no family history of any type of cancer were involved in the study.

All patients and healthy donors were asked to complete a questionnaire on their medical histories and lifestyles, including genetic disease, medication, alcohol consumption, smoking, etc.

\section{Blood sampling and isolation of cells}

Two ml of venous blood samples from each subject were drawn into heparinized tubes and were protected from light. All samples were collected in early morning before the operation. Leukocyte from $2 \mathrm{ml}$ heparinized whole blood is isolated [15], and pellets finally were washed and suspended gently on HBSS. Cells viability was greater than $98 \%$ as determined by $0.1 \%$ trypan blue exclusion. Cells numbers in the final suspension were counted using haemocytometer and adjusted to the concentration of $104-106$ cells/mL

\section{Isolation of cells from breast tissue}

A piece of tissue $(\sim 3 \mathrm{X} 3 \mathrm{~cm})$ taken from the site of the tumor was postoperatively transferred in a plain tube which contain cold phosphate buffer saline (PBS) which is used immediately for the comet assay.

The tissue put in 1-2mL of ice cold mincing solution containing 20mM EDTA and $10 \%$ DMSO. Using small dissecting scissors the tissue mince into very small pieces and let it to stand for 5 minutes, filter through four layers of nylon gauze to eliminate fibers, connective tissue, and debris. The filtrate was centrifuged at $4000 \mathrm{rpm}$ for 30 minutes at $4^{\circ} \mathrm{C}$ in order to precipitate the remaining intact cells, and then suspend cells gently on 
mincing solution. Cell viability was greater than $98 \%$ as determined by $0.1 \%$ trypan blue exclusion. Cell numbers in the final suspension was counted and adjusted to the final concentration of $106 \mathrm{cell} / \mathrm{mL}$.

\section{Comet assay}

Comet assay was modified from the method of [16]. Briefly first, the slide dip in hot $1 \%$ HMPA (High -melting point agarose). 5$10 \mu \mathrm{L}$ of cell suspension concentration ( 10.000cells) was mixed with $75 \mu$ Lof LMPA of $0.5 \%$ LMA (Low melting point agarose), and the mixture was applied to the second layer of the slide. After a third layer of $1 \%$ NMA (150 ul) was applied, the slides were immersed in cold lysing solution (2.5 $\mathrm{M} \mathrm{NaCl}, 100 \mathrm{mM}$ Na2EDTA, $10 \mathrm{mM}$ Tris, $1 \% \mathrm{~N}$-sodium lauroyl sarcosinate) for $1 \mathrm{~h}$ at $4^{\circ} \mathrm{C}$. The slides were then placed in an electrophoresis tank, allowing the DNA to unwind for $15 \mathrm{~min}$ in the alkaline solution (300 $\mathrm{mM} \mathrm{NaOH}$ and $1 \mathrm{mM} \mathrm{Na2EDTA).}$ Electrophoresis was then performed at 300 $\mathrm{mA}$ for $20 \mathrm{~min}$ in the same alkaline solution at room temperature. The slides were then neutralized by adding $0.4 \mathrm{M}$ Tris $-\mathrm{HCl}$ buffer $(\mathrm{pH} 7.5)$ and stained with ethidium bromide. TriTek comet score program was used (comet assay forum). The results were expressed as the mean comet tail moment of 50 cells. The comet tail moment is defined as the product of the percentage of cellular DNA in the comet tail and the length of DNA tail migration. The higher the comet tail moment value, the greater the amount of cellular DNA strand breaks. The tail moment is considered to be one of the best indices of comet formation obtained in computerized analysis [17] Figure I.

\section{Statistical analysis}

The data of the research were stored in Microsoft Excel Spread sheet and analyzed on the computer using the Statistical version 6 and Microsoft Excel programs. The results were expressed as mean \pm standard deviation of the mean (SD). Student t-test was applied to compare the results of patient and control groups. Differences were considered statistically significant if the $p$ value is lower than 0.05 .

\section{Results}

The characteristics of patients (benign and malignant breast tumor) and controls groups in relation to the present age, their smoking status body mass index (BMI) and site of the tumor are summarized in Table1. The mean age of control was 42 years (range: 24-65), while the mean age for men with benign breast tumor 50 years (range: 24-63), and for men with breast cancer 55years (range: 49$65)$ respectively.

All control men nonsmoking while $36.4 \%$ and $55.6 \%$ of patients with benign and malignant breast tumors smoking 1-10 cigarettes daily. On the other hand, BMI did not significantly difference between cases and control. The tumor was localized in the right side in $54.5 \%$ and $33.3 \%$ of patients with benign and malignant breast tumors correspondingly, while in the left side in $45.5 \%$ and $66 \%$ of patients with benign and malignant breast tumors in that order. In general, the susceptibility to cancer is characterized by high DNA damage, which is the result of low repair capacity. A total of 3000 cells were analyzed for DNA damage using the alkaline comet assay in breast tumor patients (blood and tissue cells) and control (blood cells only).

Table 2 shows the (mean \pm SD) comet tail moment (TM) value in the blood of the control group was $3.18 \pm 0.74$, while the mean value of comet tail moment in those with breast tumor $6.67 \pm 1.43$. Furthermore, 
in benign and malignant tumors the means of the comet tail moment were 5.64 \pm 0.88 , $7.93 \pm 0.82$, respectively Figure 2 .

Statistical analyses using student t-test showed a highly significant elevation in the mean comet tail moment level in the total breast tumor group compared to control group $(\mathrm{P}<0.0001)$. Also t-test showed significant increase in comet tail moment $(\mathrm{P}<0.0001)$ in benign and malignant as compared to those of the control group. Between groups t-test revealed statistically significant elevation $(\mathrm{P}<0.0001)$ of mean comet tail moment in malignant breast tumor as compared to benign breast tumor. For tissue cells the results are given in figure III shows there is a significant difference was observed in TM means between benign and malignant Brest tumor (11.24 \pm 1.57 versus 15.33 \pm 0.92 : $\mathrm{P}<0.0001)$.

Table 1.

Characteristics of the studied population

\begin{tabular}{|c|c|c|c|c|}
\hline \multirow{2}{*}{ Variable } & \multirow{2}{*}{ Categories } & \multirow{2}{*}{ Control } & \multicolumn{2}{|c|}{ Breast tumors } \\
\hline & & & Benign & Malignant \\
\hline Age(years) & $\begin{array}{c}\text { Mean } \pm \text { SD } \\
\text { } 0-49 \\
50-59 \\
60-69\end{array}$ & $\begin{array}{c}42.15 \pm 12.72 \\
13(65 \%) \\
5(25 \%) \\
2(10 \%)\end{array}$ & $\begin{array}{c}50.36 \pm 11.24 \\
5(45.5 \%) \\
5(45.5 \%) \\
1(9.0 \%)\end{array}$ & $\begin{array}{l}55.8 \pm 5.97 \\
1(11.1 \%) \\
6(66.7 \%) \\
2(22.2 \%)\end{array}$ \\
\hline $\begin{array}{l}\text { Smoking status } \\
\text { Smokers } \\
\text { Nonsmokers }\end{array}$ & $\begin{array}{l}\text { Mean } \pm \text { SD } \\
(1-10 / \text { day })\end{array}$ & $\begin{array}{l}- \\
20\end{array}$ & $\begin{array}{l}5.17 \pm 0.71 \\
4(36.4 \%) \\
\\
6.47 \pm 0.41 \\
7(63.6 \%) \\
\mathrm{P}=0.009 \\
\end{array}$ & $\begin{array}{c}7.25 \pm 0.62 \\
5(55.6 \%) \\
\\
\\
\\
8.50 \pm 0.39 \\
4(44.4 \%) \\
\mathrm{P}=0.007 \\
\end{array}$ \\
\hline BMI & $\begin{array}{c}\text { Mean } \pm \text { SD } \\
\geq 27 \\
\leq 27\end{array}$ & $\begin{array}{c}25.22 \pm 1.01 \\
3.31 \pm 0.78 \\
3.02 \pm 0.75\end{array}$ & $\begin{array}{c}25.62 \pm 2.00 .9 \\
4.97 \pm 0.80 \\
6.00 \pm 0.67\end{array}$ & $\begin{array}{c}26.27 \pm 1.60 \\
7.06 \pm 0.66 \\
8.36 \pm 0.48\end{array}$ \\
\hline Location of tumor & $\begin{array}{l}\text { Right breast } \\
\text { Left breast }\end{array}$ & & $\begin{array}{l}6(54.5 \%) \\
5(45.5 \%)\end{array}$ & $\begin{array}{l}3(33.3 \%) \\
6(66 . \%)\end{array}$ \\
\hline
\end{tabular}



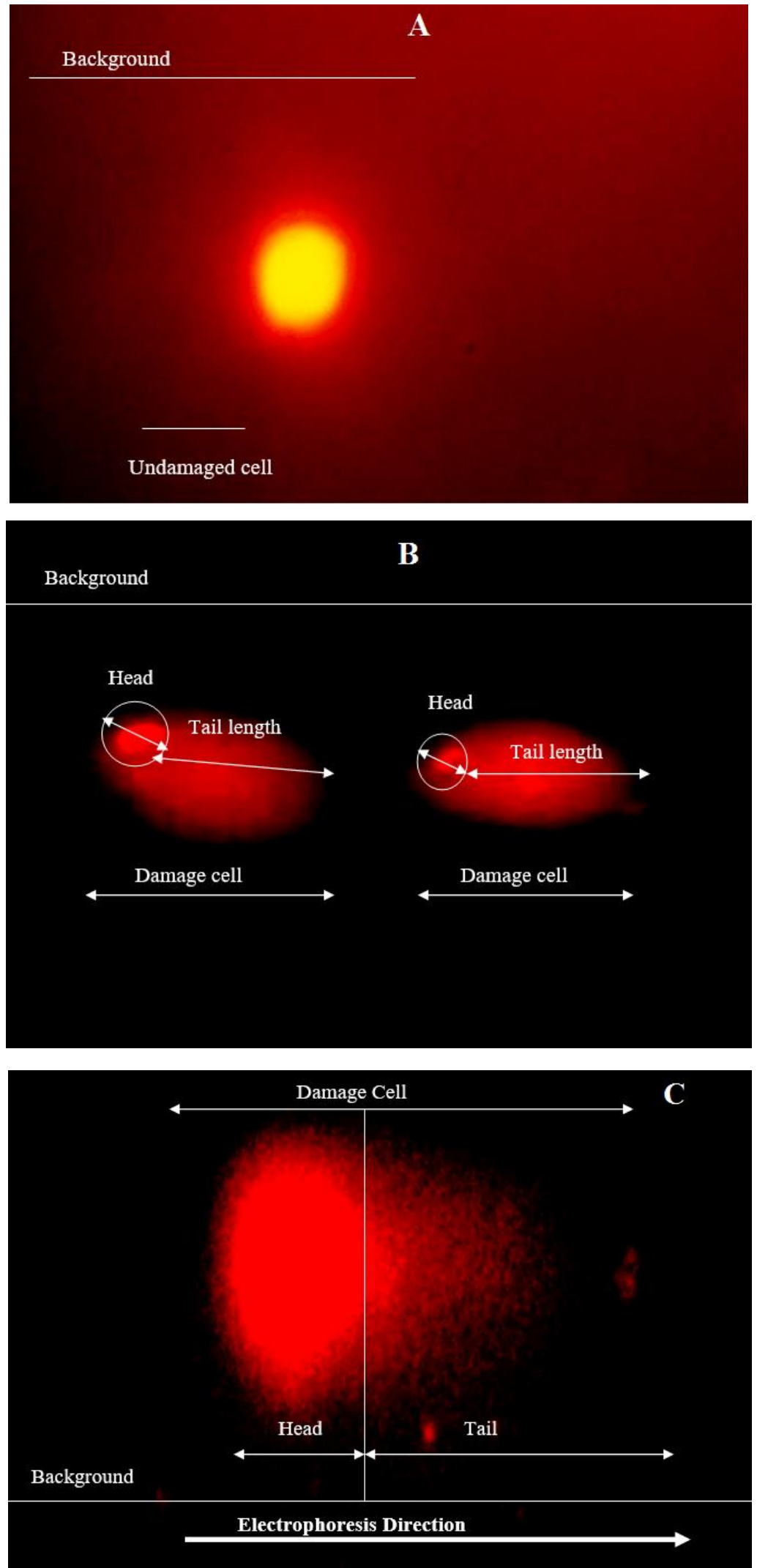

Figure I.

Photographs of single cell gel electrophoresis (SCG) stained with ethidium bromide: A intact cells. B, and $\mathbf{C}$, showing variable degree of nuclear DNA damage as revealed by changes in DNA migration comet produced by an extensive DNA damage of malignant breast cancer. 


\section{Table 2.}

The mean comet tail moment $( \pm \mathrm{SD})$ in blood leukocytes of controls, total breast tumors, benign and malignant tumor subgroups.

\begin{tabular}{|c|c|c|c|c|}
\hline Groups & $\begin{array}{c}\text { No. of } \\
\text { counted } \\
\text { cells }\end{array}$ & $\begin{array}{l}\text { Mean } \\
\text { values }\end{array}$ & SD & $P$ value \\
\hline Control & 1000 & 3.18 & 0.75 & - \\
\hline $\begin{array}{l}\text { Total } \\
\text { Breast } \\
\text { tumors } \\
\end{array}$ & 1000 & 6.45 & 1.33 & $0.001^{a^{\star \star \star}}$ \\
\hline $\begin{array}{l}\text { Benign } \\
\text { tumors }\end{array}$ & 550 & 5.64 & 0.88 & $0.0001^{a^{\star \star \star}}$ \\
\hline $\begin{array}{l}\text { Malignant } \\
\text { tumors }\end{array}$ & 450 & 7.93 & 0.82 & $\begin{array}{l}0.0001^{a^{\star \star \star}} \\
0.0001^{b^{\star \star \star}}\end{array}$ \\
\hline
\end{tabular}

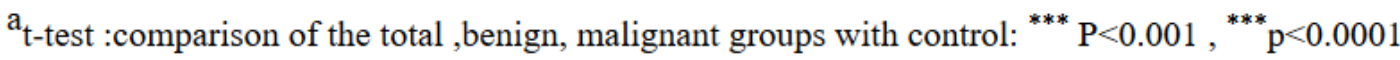

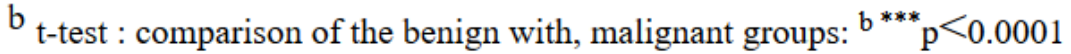

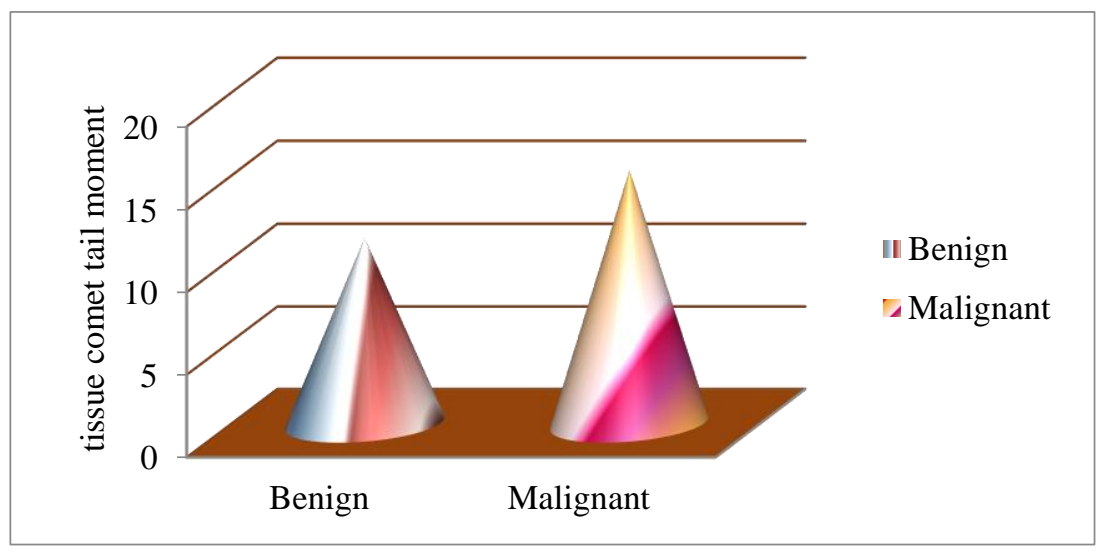

Figure 2.

The means of the DNA lesions in tissues of the benign and malignant breast tumors.

\section{Discussion}

Incidence of MBC increased significantly in the last two decades [18-20]. With an average manifestation age of about
66-71 years mostly older men suffer from this neoplasia [19, 20, and 21]. The incidence increases fatally with age [19]. The mean age of our study cases was (50 and 55 years) for benign and malignant breast 
respectively, in another study performed by Yoney et al., the mean age was reported as 58 years [22]. The mean age in our patients is lower than other countries.

In this case-control study of breast tumors, we used the comet assay to measure DNA damage and analyzed the risk for breast tumors, present study show that the cases and controls had already displayed significantly different levels of DNA damages. This difference could reflect different levels of DNA repair capacities in response to environmental and endogenous carcinogens between cases and controls. Our data were analyzed by smoking status to ensure that smoking was related to DNA damage observed in the Leukocyte of the patients with benign breast tumors and breast cancer. Since there was a significant differences observed when smoking and non-smoking patients were compared and this agreement with Bonasis et.al., and According to Faust et al., only nine human biomonitoring studies with the alkaline comet assay have found a significant relationship between DNA damage and smoking habits. However, the number of smoking patients with benign breast disease $(n=4)$ and breast cancer $(n=5)$ is not adequate to give a correct decision on smoking induced DNA damage.

Our current results showed a marginally significant interaction between BMI and DNA damage suggesting that DNA damage may serve a breast cancer risk marker in subjects with high BMI. Intriguingly, a similar interaction was observed in a previous study of breast cancer [25, 26] also for prostate cancer [27]. This finding is compatible with smith et al. in 2003 (28) who suggested that a high BMI might be associated with elevated levels of lipophilic aromatic compounds, such as polychlorinated biphenyls, aromatic and heterocyclic amines, and polycyclic aromatic hydrocarbons, stored in breast adipose tissue, leading to a continuous exposure to DNAdamaging agents. Deficient DNA repair may contribute to the accumulation of unrepaired damage in both lymphocytes and target tissue cells. This concept is supported by the evidence that higher levels of oxidative adducts were detected in breast cancer cases than in controls [28].

Our findings are supported by a larger study showing an increased breast cancer risk with the intake of well-done red meat (a potential carcinogen source) that was more pronounced in women with a high BMI [26].

When determining cancer susceptibility, it would be ideal to evaluate DNA damage and sensitivity in the target tissue, such as mammary epithelial cells, peripheral leukocytes were used in our study since it is easy and rapid to work [25]. In the present study the DNA damage in peripheral leukocytes of the patients with benign and cancer breast tumors were compared with healthy control subject's assay. It was found that the DNA damage (expressed as comet tail moment) increase in benign subtypes and malignant subtypes compared to control. This finding agrees with other studies which detected higher levels of DNA damage in breast cancer cases may be related to a combination of exposure to ROS and genetic deficiencies in DNA repair $(\mathrm{Hu}$ $[29,25,30,31]$.

Our findings support the hypothesis that DNA damage may serve as a breast cancer risk biomarker. The comet assay used in this study is sensitive to detect significant differences in single strand breaks in benign breast tumors and carcinomas. Although there is considerable evidence that individual variation in the detection, signaling, toleration, and repair of DNA damage contributes to human cancer risk. 
Numbers of studies have reported increased breast, thyroid and bladder cancer risks associated with higher DNA damage measured by the comet assay $[32,33,16$, 25].

Deficient DNA repair may contribute to the accumulation of unrepaired damage in both lymphocytes and target tissue. This concept is supported by the evidence that higher levels of oxidative adducts were detected in breast cancer cases than in controls [39, 28, 34].

In this research, benign breast tumor tissue was found to have less oxidative DNA damage than malignant tissues (expressed by comet tail moment) and this may retard the DNA repair process in malignant tissue. A number of epidemiological studies, primarily of lung and skin cancer have suggested that deficiency in DNA repair capacity contribute to accumulation of DNA damage and thus accelerate the gene rearrangements, deletions, insertions, and amplifications involved in human carcinogenesis $[40,41]$.

Paul et al., in 2002 reported that accumulation of unrepaired DNA might contribute to a variety of disorder associated with aging processes, Alic et al., found that the risk of breast and thyroid cancer also increase with the increase in the comet tail length and comet tail moment or only comet tail moment, respectively.

DNA repair capacity is essential for cell survival and the maintenance of cell cycle control. Inter-individual variation in DNA repair capacity has been observed in several in vitro lymphocyte assays [20, 23]. In addition to all these several studies have proven that the difference between DNA damage and repair capacity leads to genetic differences inducing susceptibility to carcinogenesis has been shown in many studies. Popanda et al., reported that deficiency in DNA repair is a risk factor for the development of breast cancer; Wu et al., reported that the DNA repair capacity of lung cancer patients was significantly lower than that of controls; Udumudi et al., and other researchers $[24,47,48]$ found that low DNA repair capacity is a susceptibility factor for cervical carcinoma. Recent studies have shown the DNA damage acts as an anticancer barrier. DNA damage response may serve as an inducible barrier to constrain tumor development in its early, pre-malignant stages and create environment that, over time, selects for mutations in checkpoint genes. DNA damage response may rescue defective cell growth, avoid senescence and limit cell death at the expense of genomic instability and tumor progression [19, 25-37, 49]. Thus, activation of the DNA damage check Assessment of DNA damage in peripheral blood lymphocytes Patients with Benign and Malignant Thyroid Disorders point occurs specifically in pre-neoplastic and neoplastic lesions. Some benign proliferative lesions, both with and without atypia, seem to contain precursor mutations that might affect neoplastic potential [28, 50]. This concept has been formulated, based on the results obtained from analyses of human solid tumors derived from somatic cells, including the various stages of lung, urinary bladder, colorectal, breast cancer and melanomas, as well as some mouse tumor models and cultured human somatic cells $[19,26,27,34,49]$.

In conclusion; our results support the hypothesis that increased breast cancer risk is associated with higher DNA damage and evaluation of DNA damage response may contribute to early detection and prevention of breast cancer but due to enhanced proliferative index in certain benign 
disorders, use of DNA damage only may not be sufficient to show risk of progression to cancer. Studies with larger population and also in other cells apart from lymphocytes are necessary. On the other hand; our results also show that comet assay seems to be reliable, rapid, and sensitive method for detecting DNA damage in individual cells and fulfils the requirements of a biological marker to detect/ breast cancer risk.

\section{Competing interests}

The author declares that there is no conflict of interest.

\section{References}

1. Martynowicz H, Medraś M, Andrzejak R. Occupational risk factors and male breast cancer. Medycyna Pracy 2005;56:405-10.

2. Lambley J, Maguire E, Lam KY. Synchronous bilateral breast cancer in an elderly man. Breast J 2005;11:153.

3. Forloni F, Giovilli M, Pecis C, et al. Pituitary prolactin-secreting macroadenoma combined with bilateral breast cancer in a 45 -yearold male. J EndocrinolInvst 2001;24:454-459.

4. Volm MD, Talamonti MS, Thangavelu M, Gradisher WK. Pituitary adenoma and bilateral male breast cancer: an unusual association. J SurgOncol 1997;64:74-78.

5. Olsson H, Alm P, Kristoffersson U, LandinOlsson M. Hypophyseal tumor and gynecomastia preceding bilateral breast cancer development in a man. Cancer 1984; 1974-1977.

6. Cutuli B. Strategies in treating male breast cancer. Expert Opin Pharmacother 2007; 8:93-202.

7. Giordano SH. A review of the diagnosis and management of male breast cancer. Oncol 2005;10:471-479.

8. Narod SA, OffitK. Prevention and management of hereditary breast cancer. J Clin Oncol 2005;23:1656-1663.

9. Swerdlow AJ, Schoemaker MJ, Higgins CD, Wright AFand Jacobs PA. Cancer incidence and mortality in men with Klinefelter syndrome: A Cohort study. J Natl Cancer Inst 2005;97:1204-1210.

10. Calderon-Garciduenas L, Osnaya N, Rodriguez-Alcaraz A, Villareal-Calderon A. DNA damage in nasal respiratory epithelium from children exposed to urban pollution. Environ. Mol. Mutagen 1997;30:11-20.

11. Andreoli C, Leopardi P, Crebelli R. Detection of DNA damage in human lymphocytes by alkaline single cell gel electrophoresis after exposure to benzene or benzene metabolites. Mutat. Res 1997;377:95-104.

12. Vodicka P, Tvordik T, Osterman-Golkar S. An evaluation of styrene genotoxicity using several biomarkers in a 3-year follow-up study of hand-lamination workers. Mutat. Res 1999;445:205-224.

13. Zhu CQ, Lam TH, Jiang CQ, et al. Lymphocyte DNA damage in cigarette factory workers measured by the Comet Assay. Mutat. Res 1999;444:1-6.

14. Moller P, Knudsen LE, Loft S, Wallin H. The comet assay as a rapid test in biomonitoring occupational exposure to DNA-damaging agents and effect of confounding factors. Cancer Epidem. Biomar. Prev 2000;9:1005-1015.

15. Nath N, Chari SN, Rathi AB. superoxide dismutase in diabetic polymorphonuclear leukocytes. Diabetes 1984;33:586-589.

16. Singh NP, McCoy MT, Tice RR, Schneider. A simple technique for quantitation of low levels of DNA damage in individual cells. Exp Cell Res 1988;175:184-91.

17. Chuang $\mathrm{CH}, \mathrm{Hu}$ ML. Use of whole blood directly for single-cell gel electrophoresis (comet) assay in vivo and white blood cells for in vitro assay. Mutat Res 2004;564:75-82.

18. Hodgson NC, Button JH, Franceschi D, Moffat FL, Livingstone AS. Male breast cancer: is the incidence increasing? Ann Surg Oncol 2004;11:751-5.

19. Giordano SH. A review of the diagnosis and management of male breast cancer. Oncologist 2005;10:471-9.

20. Joseph A, Mokbel K. Male breast cancer. Int J FertilWomens Med 2004;49:198-9. 
21. Weiss JR, Moysich KB, and Swede H. Epidemiology of male breast cancer. Cancer Epidemiol Biomarkers Prev 2005;14:20-6.

22. Yoney A,Kucuk A, Unsal M. Male breast cancer: A retrospective analysis. Cancer/ Radiothérapie 2009;13:103-107.

23. Bonassi S, Neri M, Lando C, et al. Effect of smoking habit on the frequency of micronuclei in human lymphocytes: results from the Human Micro-Nucleus project. Mutat. Res 2003;543:155-166.

24. Faust F, Kassie F, Knasmüller S, et al. The use of the alkaline comet assay with lymphocytes in human biomonitoring studies. Mutat. Res 2004;566:209-229.

25. Smith TR, Miller MS, Lohman KK, Case LD, HuJ. DNA damage and breast cancer risk. Carcinogenesis 2003;24:883-889.

26. Dai Q, ShuXO, Jin F, Gao YT, Ruan ZX, Zheng W. Consumption of animal foods, cooking methods, and risk of breast cancer. Cancer Epidemiol. Biomarkers Prev 2002; 11:801-808.

27. Kathryn M, Belinda C, Richard D. Male breast cancer: Progress, prognosis and future pathways. Asia-Pacific Journal of Clinical Oncology 2008;4:6-17.

28. Lucena R, Allam M, Costabeber I, Villarejo M, Navajas R. Breast cancer risk factors: PCB congeners. Eur. J. Cancer Prev 2001; 10:117-119.

29. Hu J, Smith T, Miller M, Lohman K. Case L. Genetic regulation of ionizing radiation sensitivity and breast cancer risk. Environ. Mol. Mutagen 2002;39:208-215.

30. Colleu-Durel S, Guitton N, Nourgalieva K, et al. Alkaline single-cell gel electrophoresis (Comet assay): a simple technique to show genomic instability in sporadic breast cancer. Eur J Cancer 2004;40:445-451.

31. Hussen MM, McNulty H, Armstrong N, Johnston PG, Spence R, Barnett Y. Investigation of systemic folate status, impact of alcohol intake and levels of DNA damage in mononuclear cells of breast cancer patients. Br J Cancer 2005;92:1524-1530.

32. Sigurdson A, Hauptmann M, Alexander B, et al. DNA damage among thyroidcancer and multiple cancer cases, controls, and longlived individuals. Mutat. Res 2005;586:173188.

33. Schabath M, Spitz M, Grossmann H, et al. Genetic instability in bladder cancer assessed by the comet assay. J. Natl. Cancer Inst 2003;95:540-547.

34. Li D, Wang M, Dhingra K, Hittelman W. Aromatic DNA adducts in adjacent tissues of breast cancer patients: clues to breast cancer etiology. Cancer Res 1996;56:287-293.

35. Li D, Zhang W, Sahin A, Hittelman N. DNA adducts in normal tissue adjacent to breast cancer: a review. Cancer Detect. Prev. 1999;23:454-462.

36. Li D, Zhang W, Zhu J, et al. Oxidative DNA damage and 8-hydroxy-2-deoxyguanosine DNA glycosylase/apuriniclyase in human breast cancer. Mol. Carcinogen 2001; 31:214-223.

37. Musarrat J, Arezina-Wilson J, Wani A. Prognostic and etiological relevance of 8hydroxyguanosine in human breast carcinogenesis. Eur. J. Cancer1996;32A: 1209-1214.

38. Malins DC, Haimanot R. Major alterations in the nucleotide structure of DNA in cancer of the female breast. Cancer Res 1991;5 1:5430-5432.

39. Rundle A, Tang D, Hibshoosh H, et al. The relationship between genetic damage from polycyclic aromatic hydrocarbons in breast tissue and breast cancer. Carcinogenesis 2000;21:1281-1289.

40. Berwick M, Vinesis P. Markers of DNA repair and susceptibility to cancer in human: an epidemiologic review. J. Natl. Cancer Int 2000;92:874-97.

41. Benhamou S, Sarasin A. Variability in nucleotide excision repair and cancer risk: a review. Mutat. Res 2000;462-58.

42. Paul H, Raymond R, Chris J, et al. Application of single-cell gel electrophoresis (comet) assay for assessing level of DNA damage in canine and feline leukocytes. J.Nutr 2002;132:1598S-1603S.

43. Alice $S$, Michael H, Bruce $H$, et al. DNA damage among thyroid cancer and multiple 
cancer cases, control, and long-lived individuals. Mutation Research 2005;586: 173-188.

44. Popanda O, Ebbeler R, Twardella D, et al. Radiation-induced DNA damage and repair in lymphocytes from breast cancer patients and their correlation with acute skin reactions to radiotherapy. Int. J. Radiat. Oncol. Biol. Phys 2003;55;1216-1225.

45. Wu X, Zhao H, Wie Q, et al. XPA polymorphism associated with reduced lung cancer risk and a modulating effect on nucleotide excision repair capacity. Carcinogenesis 2003;24:505-509.

46. Udumudi A, Jaiswal M, Rajeswari N, et al. Risk assessment in cervical dysplasia patients by single cell gel electrophoresis assay: a study of DNA damage and repair. Mutat. Res 1998;412:195-205.

47. Ülkü Ü, Tevfik Ş, Osman Y,Hasan B, Osman K, Ferit T, Nurşen B. Assessment of DNA Damage in PeripheralBlood Lymphocytes From Patients with Benign and Malignant Thyroid Disorders. Hacettepe University Journal of the Faculty of Pharmacy 2008;28:1-14.
48. Iarmarcovai G. Sari-Minodier I. Chaspoul F. et al. Risk assessment of welders using analysis of eight metals by ICP-MS in blood and urine and DNA damage evaluation by the comet and micronucleus assays; influence of XRCC1 and XRCC3 polymorphisms. Mutagenesis 2005;20(6):425-432.

49. Kristin L, Lockett M, Craig H, et al. DNA damage levels in prostate cancer cases and controls. Carcinogenesis 2006;27(6):11871193.

50. Gorlewska-RobertsK, Green B, Fares M, Ambrosone CB, Kadlubar F. CarcinogenDNA adducts in human breast epithelial cells. Environ. Mol. Mutagen 2002;39:184192.

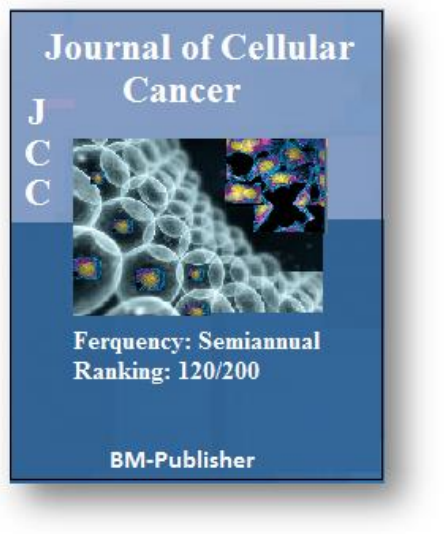

